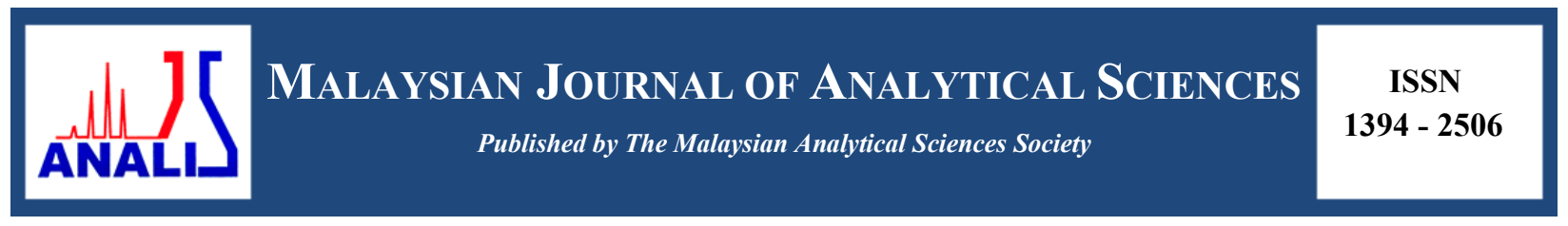

\title{
CATALYTIC CRACKING OF USED VEGETABLE OIL TO GREEN FUEL WITH METAL FUNCTIONALIZED ZSM-5 CATALYSTS
}

\author{
(Pemecahan Bermangkin Minyak Sayur Terpakai kepada Bahan Api Hijau dengan Pemangkin \\ ZSM-5 Berfungsi Logam)
}

\author{
Mohamed Azeem Abdul Majed and Ching Thian Tye* \\ School of Chemical Engineering, Engineering Campus \\ Universiti Sains Malaysia, 14300 Nibong Tebal, Penang, Malaysia \\ ${ }^{*}$ Corresponding author: chcttye@usm.my
}

Received: 6 September 2017; Accepted: 8 January 2018

\begin{abstract}
Depletion of fossil fuel reserves and environmental issue have led to the development of biofuels. Plant derived oil, such as palm oil, has been claimed as one of the promising source of renewable energy. However, high oxygen content in palm oil makes it unsuitable to be directly used as fuel. In the present study, the performance of Ni/ZSM-5, Mo/ZSM-5 and NiMo/ZSM-5 catalysts was investigated in catalytic cracking of used vegetable oil (UVO) into green fuel. The catalytic cracking reactions were carried out in a fixed bed reactor at 4 hour $^{-1}$ (WHSV), continuously for 3 hours. Conversions of the two major fatty acids: palmitic acid $(84.72 \%)$ and stearic acid $(74.10 \%)$ were found highest at $350{ }^{\circ} \mathrm{C}$ with $\mathrm{Mo} / \mathrm{ZSM}-5$. The optimum palmitic acid and stearic acid conversion with Mo/ZSM-5 were found at $400{ }^{\circ} \mathrm{C}$. Comparison study was also done with $\mathrm{Pd} / \mathrm{Al}_{2} \mathrm{O}_{3}$ at $400{ }^{\circ} \mathrm{C}$ for its performance in catalytic cracking of UVO. Similar conversion for palmitic acid was obtained for Mo/ZSM-5 (84.72\%) and Pd/Al $\mathrm{O}_{3}$ $(86.37 \%)$ at steady state. However, system with Mo/ZSM-5 as catalyst approached steady state earlier at 60 mins compared to that of $\mathrm{Pd} / \mathrm{Al}_{2} \mathrm{O}_{3}$ at 120 minutes.
\end{abstract}

Keywords: catalytic cracking, used vegetable oil, green fuel, ZSM-5

\begin{abstract}
Penurunan rizab bahan api fosil dan isu alam sekitar telah membawa kepada pembangunan bahan api bio. Minyak daripada tumbuhan, seperti minyak kelapa sawit telah dituntut sebagai salah satu sumber tenaga boleh diperbaharui yang menjanjikan. Namun, kandungan oksigen yang tinggi dalam minyak kelapa sawit menjadikannya tidak sesuai digunakan secara terus sebagai bahan bakar. Dalam kajian ini, prestasi pemangkin Ni/ZSM-5, Mo/ZSM-5 dan NiMo/ZSM-5 telah diuji dalam pemecahan bermangkin minyak sayuran terpakai (UVO) kepada bahan api hijau. Tindak balas pemecahan bermangkin tersebut adalah dijalankan dalam reaktor lapisan tetap pada 4 jam $^{-1}$ (WHSV), secara berterusan selama 3 jam. Penukaran kedua-dua asid lemak utama: asid palmitik (84.72\%) dan asid stearik (74.10\%) didapati paling tinggi pada $350{ }^{\circ} \mathrm{C}$ dengan Mo/ZSM-5. Penukaran optimum asid palmitik dan asid stearik dengan Mo/ZSM-5 didapati pada $400{ }^{\circ} \mathrm{C}$. Kajian perbandingan juga dilakukan dengan $\mathrm{Pd} / \mathrm{Al}_{2} \mathrm{O}_{3}$ pada suhu $400{ }^{\circ} \mathrm{C}$ untuk prestasinya dalam pemecahan bermangkin UVO. Penukaran yang sama telah diperolehi untuk asid palmitik dengan Mo/ZSM-5 (84.72\%) dan $\mathrm{Pd} / \mathrm{Al}_{2} \mathrm{O}_{3}(86.37 \%)$ pada keadaan mantap. Namun begitu, sistem yang menggunakan Mo/ZSM-5 sebagai pemangkin mencecah keadaan mantap lebih awal pada 60 minit berbanding dengan $\mathrm{Pd} / \mathrm{Al}_{2} \mathrm{O}_{3}$ pada 120 minit.
\end{abstract}

Kata kunci: pemecahan bermangkin, minyak sayuran terpakai, bahan api hijau, ZSM-5 


\section{Introduction}

It is reported that biofuel leads to greenhouse gas reductions, on a well-to-wheel basis, of $40-60 \%$ when compared with conventional petroleum diesel [1]. In the USA alone, over 1.5 billion gallons of biofuel was produced from vegetable oils in year 2016 [2]. Meanwhile, global biodiesel production and consumption is forecast to rise by $14 \%$ from 2016 to 2020, driven by the fulfillment of current biofuel policies in the US, Argentina, Brazil, Indonesia and the EU. At the meantime, the biodiesel from waste-based production was forecast to grow to 4.4 billion liters [3].

Catalytic cracking is a process widely used in petroleum refining for converting heavy portion into lighter products. Catalytic cracking of vegetable oil into green fuel is favorable as it does not require additional infrastructure to be build [4]. The process can be carried out in the catalytic cracker in the conventional petroleum refinery. Further, green fuel derived from it has the similar chemical properties as the conventional petroleum fuel and can be used directly as the fossil derived fuel. This is attractive as compared to biofuel produced from transesterification of vegetable oil with ethanol or methanol that being converted to fatty acid methyl ester (FAME). Unlike green diesel, biodiesel can only be used in diesel engines blended $(<20 \%)$ with diesel in order to avoid excessive buildup of carbon in diesel engines. Another major issue with the biodiesel is the tendency to freeze at low temperature, which makes it not suitable to be used in winter or other cold period of the year [5]. Therefore, production of green fuel from catalytic cracking is getting more attention. Zeolite is one of the most common catalysts used in catalytic cracking reaction $[6,7,8]$. Its tunable acid-basic properties, easy modification by ion exchange and molecular sieving properties make it widely favorable [8].

There are a few common types of zeolites, such as ZSM-5, $\beta$ zeolite, $\gamma$ zeolite, Mordenite, silico alumino phosphate and several mesoporous materials, were studied in converting vegetable oil into biofuels $[9,10]$. Several studies reported catalytic cracking of pure vegetable oils, like cottonseed [11], sunflower [12] and palm oils [10, 13] with the yields of gasoline being about $30 \%$ in all the cases. Some reported catalytic cracking of mixture of 5-10\% vegetable oil with vacuum gas oil $[4,12]$. Most studies were carried out with commercial zeolite catalyst. Snåre et al. [14] studied a series of metals of high selectivity performance: palladium (Pd), platinum (Pt), nickel (Ni), ruthenium $(\mathrm{Ru})$, rhodium $(\mathrm{Rh})$ and Osmium $(\mathrm{Os})$ towards conversion or deoxygenation of stearic acid in vegetable oil. Pd and Pt metal catalyst was reported to give a promising performance [14-17]. Later, there were several studies on Pd base catalysts such as $\mathrm{Pd} / \mathrm{ZSM}-5$ [18] and $\mathrm{Pd} / \mathrm{SiO}_{2}[19]$ on cracking or deoxygenation in biofuel production and derivatives. Recently, $\mathrm{TiO}_{2}$ has also been tested as potential catalyst for deoxygenation of triglyceride to hydrocarbon-like biofuel [20]. Although these noble metals gave promising performance, the price is very expensive. Catalyst with similar performance and lower price is essential for an economic process.

Nickel (Ni) and molybdenum (Mo) are transition metals of group 10 and group 6 elements in periodic table, respectively. These two transition metals were chosen in this study for zeolite functionalization. Ni was chosen due to its properties similar with other group 10 element such as Pd and Pt [21]. On the other hand, Mo is a transition metal which is commonly used as catalyst in various cracking and treating of petroleum products. The main objective of the present study is to study the performance of a series of metal functionalized zeolite in catalytic cracking of UVO in order to explore for a more efficient and cheaper catalyst.

\section{Materials}

Materials and Methods

The feedstock, waste cooking oil used in the reaction was collected from the Universiti Sains Malaysia's engineering campus cafeteria. For catalyst preparation, ammonium molybdate tetrahydrate, $\left(\mathrm{NH}_{4}\right)_{6} \mathrm{Mo}_{7} \mathrm{O}_{24} \cdot 4 \mathrm{H}_{2} \mathrm{O}(\geq$ 99\%) and $5 \mathrm{wt} \%$ palladium on alumina, $\mathrm{Pd} / \mathrm{Al}_{2} \mathrm{O}_{3}$ were from Aldrich. ZSM-5 zeolite (CV2314) was from Zeolyst International and nickel (II) nitrate, $\mathrm{Ni}\left(\mathrm{NO}_{3}\right)_{2} \cdot 6 \mathrm{H}_{2} \mathrm{O}(99 \%)$ used was from Acros. Palmitic acid, as the model compound was from Merck.

\section{Catalyst preparation}

Zeolite based catalysts prepared in the present study were functionalized with different metals. Incipient wetness impregnation method was applied to load different type of metals at $5 \mathrm{wt} \%$ on ZSM-5 zeolite. Firstly, the desired amount of zeolite ( $95 \mathrm{wt} \%$ ) and metal precursor ( $5 \mathrm{wt} \%$ metal equivalent), such as $\mathrm{Ni}\left(\mathrm{NO}_{3}\right)_{2} \cdot 6 \mathrm{H}_{2} \mathrm{O}$ was dissolved in deionized water. Then, the mixture was stirred at room temperature for 8 hours to enhance the distribution of metal 
precursor on ZSM-5. Next, the mixture was dried in the oven at $120^{\circ} \mathrm{C}$ for 16 hours. The dried material was then calcined at $550{ }^{\circ} \mathrm{C}$ for 2 hours in a furnace. The formed catalyst is termed Ni/ZSM-5. The procedure was repeated by replacing nickel precursor with $\left(\mathrm{NH}_{4}\right)_{6} \mathrm{Mo}_{7} \mathrm{O}_{24} \cdot 4 \mathrm{H}_{2} \mathrm{O}$ as molybdenum precursor at metal loading of $5 \mathrm{wt} \%$ to obtain Mo/ZSM-5 catalyst. Catalyst prepared after calcinations is in oxide form. In order to obtain ZSM-5 with reduced metal, a reduction step would be performed in-situ prior to the catalytic cracking reaction.

\section{Catalyst characterization}

The metal functionalized zeolites prepared were characterized by using $x$-ray diffraction (XRD), scanning electron microscopy (SEM) and energy dispersive $x$-ray (EDX) spectroscopy. XRD was carried out using a Philips $x$-ray diffractometer (generator: PW 1729, Goniometer: PW 1820, diffraction controller: PW 1710). The diffractometer was used with monochromatized $\mathrm{Cu}-\mathrm{K}_{\alpha}$ radiation at $\lambda=0.15418 \mathrm{~nm}$ and taken in the range of $10^{\circ}$ to $90^{\circ}(2 \theta)$. The $x$ ray tube was operated at $40 \mathrm{kV}$ and $120 \mathrm{~mA}$. SEM was carried out by using a Scanning Electron Microscope model Leo Supra 50 VP Field Emission. The SEM unit was equipped with an INCA 400 Energy Dispersive X-ray (EDX) microanalyser with an operating voltage in the range of $0.1 \mathrm{kV}$ to $30 \mathrm{kV}$. The EDX analysis used $\mathrm{Mn} \mathrm{K}_{\alpha}$ as the energy source operated at $15 \mathrm{kV}$ of accelerating voltage, $155 \mathrm{eV}$ resolution with $22.4^{\circ}$ take off angle.

\section{Catalyst activity test}

The catalytic cracking reactions of UVO were conducted in a fixed-bed reactor system with reactor outer diameter of $1 / 2$ inch as shown in Figure 1. First, $1 \mathrm{~g}$ of catalyst was loaded on top of the flattened quartz wool. The reactor's temperature was raised to the desired reaction temperature in a tube furnace (Nabertherm B170). A mass flow controller (model M100B by MKS Instrument) was used to control the flow of hydrogen or nitrogen gas into the reactor. Prior to a reaction, whenever necessary, a catalyst reduction step was carried out by flowing through hydrogen $\left(100 \mathrm{~cm}^{3}(\mathrm{STP}) \mathrm{min}^{-1}\right)$ for 2 hours at $200^{\circ} \mathrm{C}$ with starting heating rate at $10{ }^{\circ} \mathrm{C} \mathrm{min}^{-1}$. Then, the reactor system was switched to $10 \mathrm{ml} / \mathrm{min}$ of $\mathrm{N}_{2}$ flow. $\mathrm{N}_{2}$ gas was used as the carrier gas in the reaction. The reactant, UVO in a volumetric flask with magnetic stirrer stirring continuously, was charged into the reactor from the top using a Series I high performance metering pump by Lab Alliance. The feed rate was set at 4 hour ${ }^{-1}$ (weight hourly space velocity, WHSV). The reaction time was considered to start once the metering pump was started. The liquid product samples were collected from the bottom of the reactor via outlet tubing every half an hour interval continuously for 3 hrs.

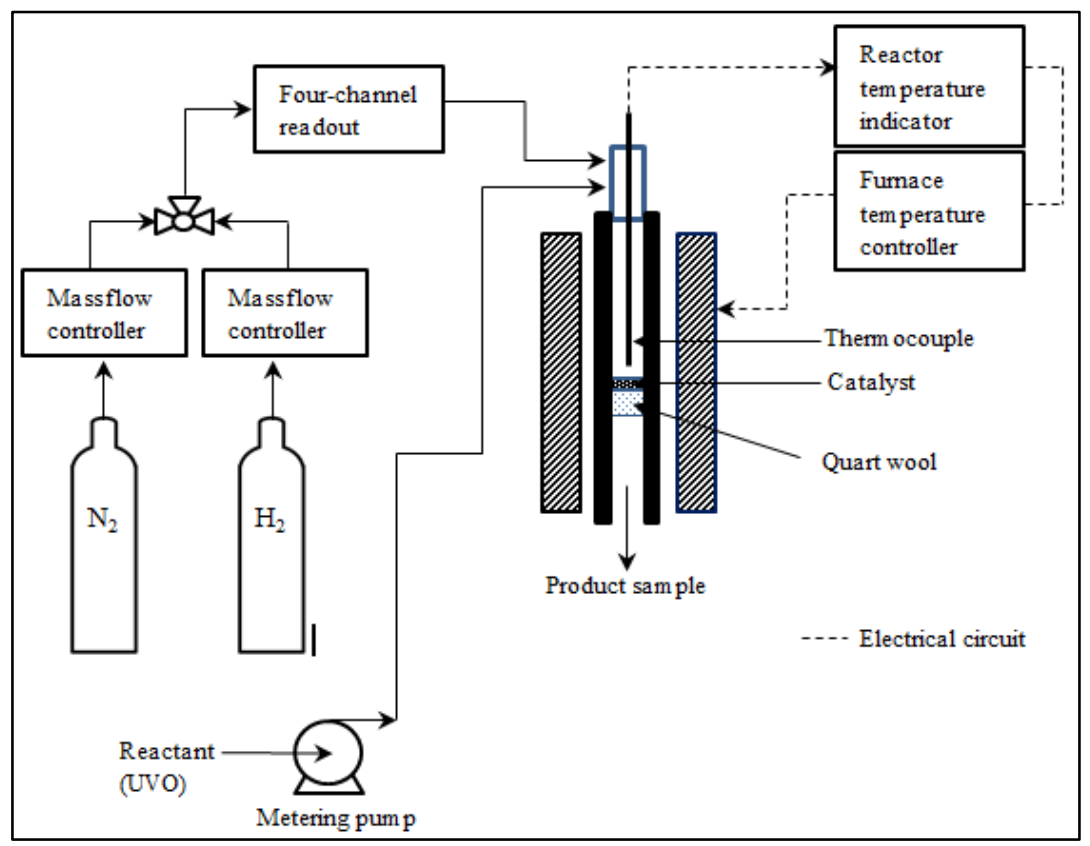

Figure 1. Schematic diagram of fixed bed reactor system 


\section{Product analysis}

Possible components of liquid products were identified by gas chromatograph-mass spectrometer (GC-MS). The liquid products were analyzed by using gas chromatography (GC-FID) equipped with a flame ionization detector (FID) and a NUKOL column with dimension of $15 \mathrm{~m} \times 0.53 \mathrm{~mm} \times 0.5 \mu \mathrm{m}$. The gas chromatography oven temperature program was set at: initial oven temperature at $110^{\circ} \mathrm{C}$ and hold it for 0.5 minutes, heating from $110^{\circ} \mathrm{C}$ to $220^{\circ} \mathrm{C}$ at $10^{\circ} \mathrm{C} / \mathrm{min}$ and finally hold $220^{\circ} \mathrm{C}$ for 10 minutes.

\section{Catalyst characterization}

\section{Results and Discussion}

ZSM-5 used was the aluminosilicate zeolite with $\mathrm{SiO}_{2} / \mathrm{Al}_{2} \mathrm{O}_{3}$ mole ratio of 23 and $\mathrm{Na}_{2} \mathrm{O}$ of 0.05 wt $\%$. It has large surface area of $425 \mathrm{~m}^{2} / \mathrm{g}$. Elements such as $\mathrm{Al}, \mathrm{C}, \mathrm{O}, \mathrm{Si}$, and $\mathrm{Na}$ are present in ZSM-5 [22]. However, EDX spectroscopy did not detect Al and Na. According to Danilina et al. [23], aluminum in ZSM-5 crystallized structure was preferentially located in the rim, while silicon and oxygen were well distributed. Because of its limited penetration, EDX could have failed to detect the enrichment.

Anyhow, the EDX Spectroscopy does show that the metal has successfully loaded onto the zeolite. EDX results are shown in Figure 2. If any foreign element or impurity presents in the catalyst, it can be identified. EDX showed there is no impurity in all three tested catalysts.
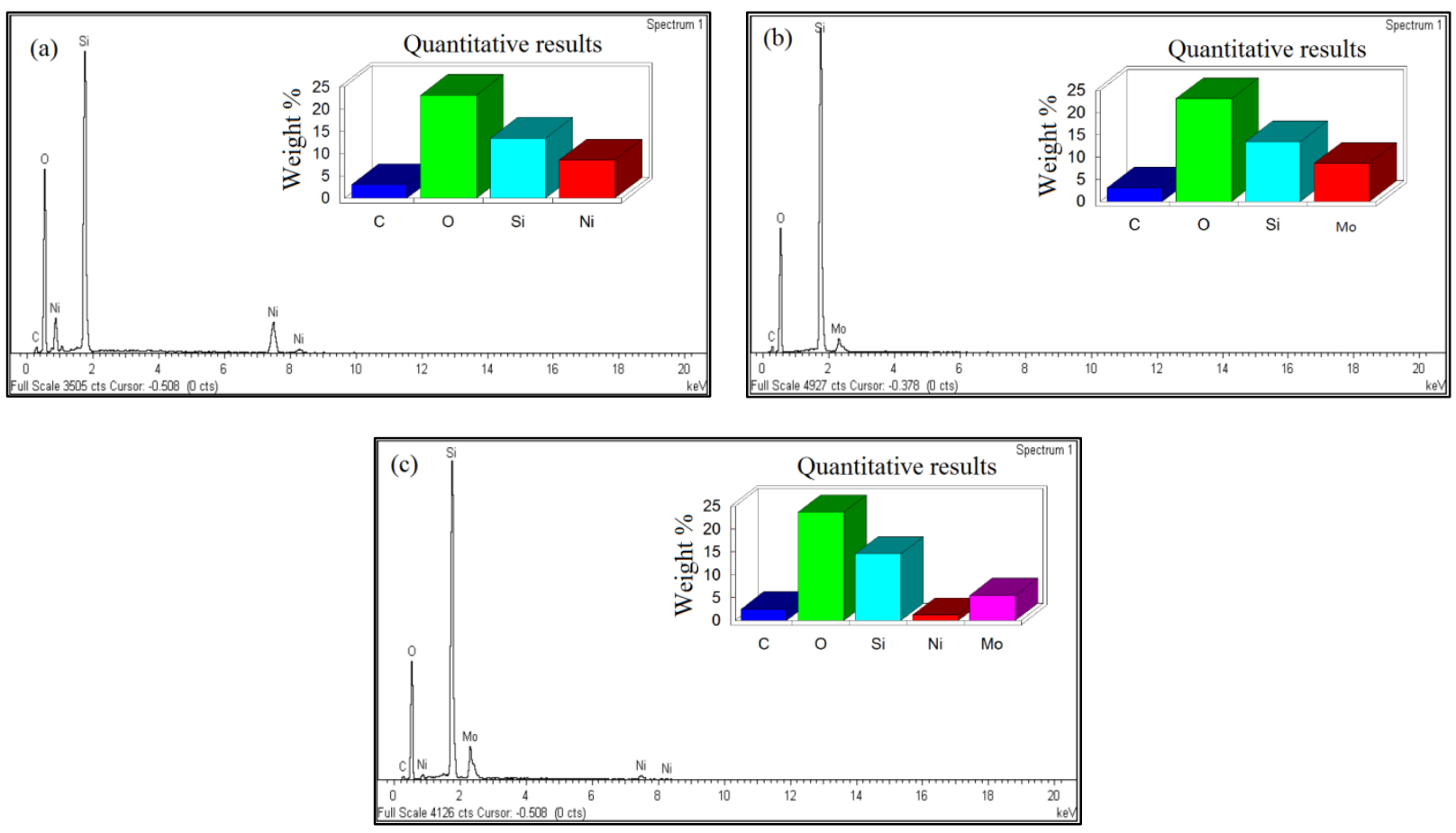

Figure 2. EDX Spectroscopy of (a) Ni/ZSM-5, (b) Mo/ZSM-5 and (c) NiMo/ZSM-5

The SEM images of Ni/ZSM-5, Mo/ZSM-5 and NiMo/ZSM-5 at magnification of 10 000x are shown in Figure 3. The figure shows that all three catalysts are porous with well-formed particle of sphere-like-structure. These porous structure make the material possessed a large surface area. However, the particles are non-uniform due to different metals were impregnated on ZSM-5. 

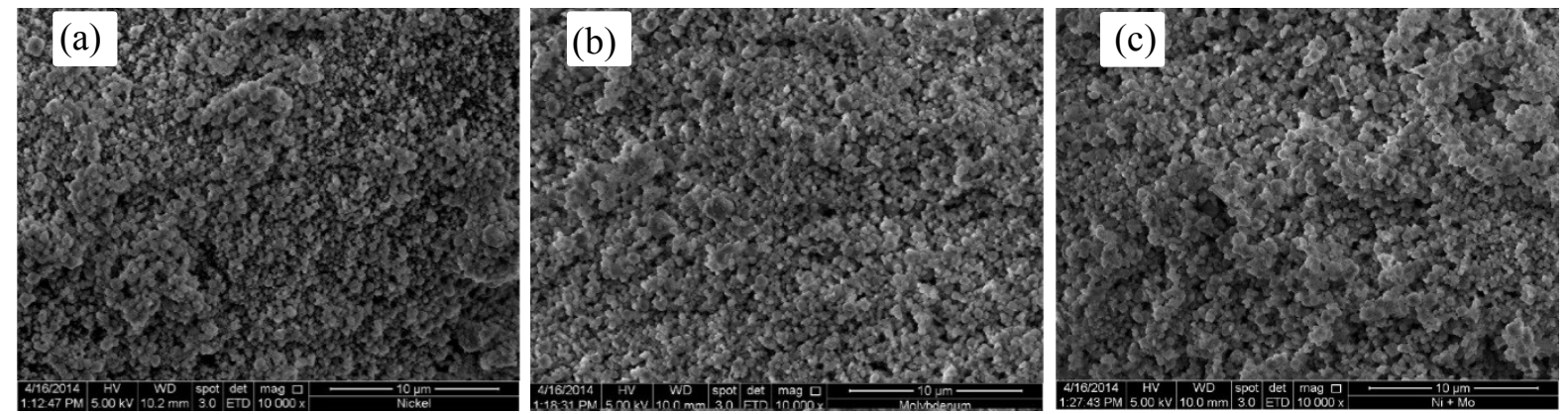

Figure 3. SEM images of (a) Ni/ZSM-5, (b) Mo/ZSM-5, (c) NiMo/ZSM-5 at magnification of 10000x

From XRD analysis (XRD spectra not shown), nickel and molybdenum oxides as expected were formed. Oxide formed on Ni/ZSM-5 was identified as monoclinic nickel oxide, $\mathrm{NiO}$, while crystalline structure of orthorhombic molybdenum trioxide, $\mathrm{MoO}_{3}$ was formed on Mo/ZSM-5. For NiMo/ZSM-5, in addition to nickel oxide and molybdenum trioxide, crystalline monoclinic nickel molybdenum oxide, $\mathrm{NiMoO}_{4}$ had also been identified.

\section{Different metal functionalized ZSM-5 catalyst in catalytic cracking of UVO}

In the current study, two major types of fatty acids, namely palmitic acid, $\mathrm{C}_{16} \mathrm{H}_{32} \mathrm{O}_{2}(86.9 \%)$ and stearic acid, $\mathrm{C}_{18} \mathrm{H}_{36} \mathrm{O}_{2}(13.1 \%)$, were identified from the UVO composition. This is different from the other studies using palm oil as feedstock, where significant oleic acid (40-53\%) and linoleic acid (6-14\%) were found [24, 25]. This could be due to the different compositions of the fresh cooking oil used, the different cooking conditions and the food cooked.

From previous study by Chiam and Tye [26], a significant amount of alkane and alkene had been found in the liquid product after a non-catalytic thermal reaction of the UVO. It can tell that cracking and deoxygenation of fatty acids to alkane and alkene occurred during the reaction at high temperature $\left(>300{ }^{\circ} \mathrm{C}\right)$. Therefore, it can be deduced that higher conversion of fatty acid leads to higher production of lighter oil in the system. Due to the complex mixture of different types of cracking fatty acid products formed in the liquid such as decanoic acid $\left(\mathrm{C}_{10} \mathrm{H}_{20} \mathrm{O}_{2)}\right.$, lauric acid, $\left(\mathrm{C}_{12} \mathrm{H}_{24} \mathrm{O}_{2}\right)$, tetradecanoic acid $\left(\mathrm{C}_{14} \mathrm{H}_{28} \mathrm{O}_{2}\right)$, oleic acid $\left(\mathrm{C}_{18} \mathrm{H}_{34} \mathrm{O}_{2}\right)$ etc. in the present study, the catalyst cracking activities were compared in terms of the conversion of palmitic acid and stearic acid.

ZSM-5 and ZSM-5 functionalized with different reduced metals: Ni, Mo and NiMo were tested for their catalytic cracking activities of UVO. As shown in Figure 4(a), generally the conversion of palmitic acid reached steady state after 60 minutes of the catalytic cracking reaction of UVO except for the reaction using pure ZSM-5 zeolite as catalyst. The conversion of the palmitic acid for different catalyst used is in increasing order of ZSM-5 $(50.66 \%)<$ Ni/ZSM-5 (60.84\%) < NiMo/ZSM-5 (76.75\%) < Mo/ZSM-5 (84.72\%) after 150 minutes. Similar trend was observed for conversion of stearic acid: ZSM-5 (48.02\%) < Ni/ZSM-5 (60.43\%) < NiMo/ZSM-5 (67.01\%) < Mo/ZSM-5 (74.10\%). This clearly shows that the Mo/ZSM-5 gives the highest conversion of both palmitic acid and stearic acid in catalytic cracking of UVO. 

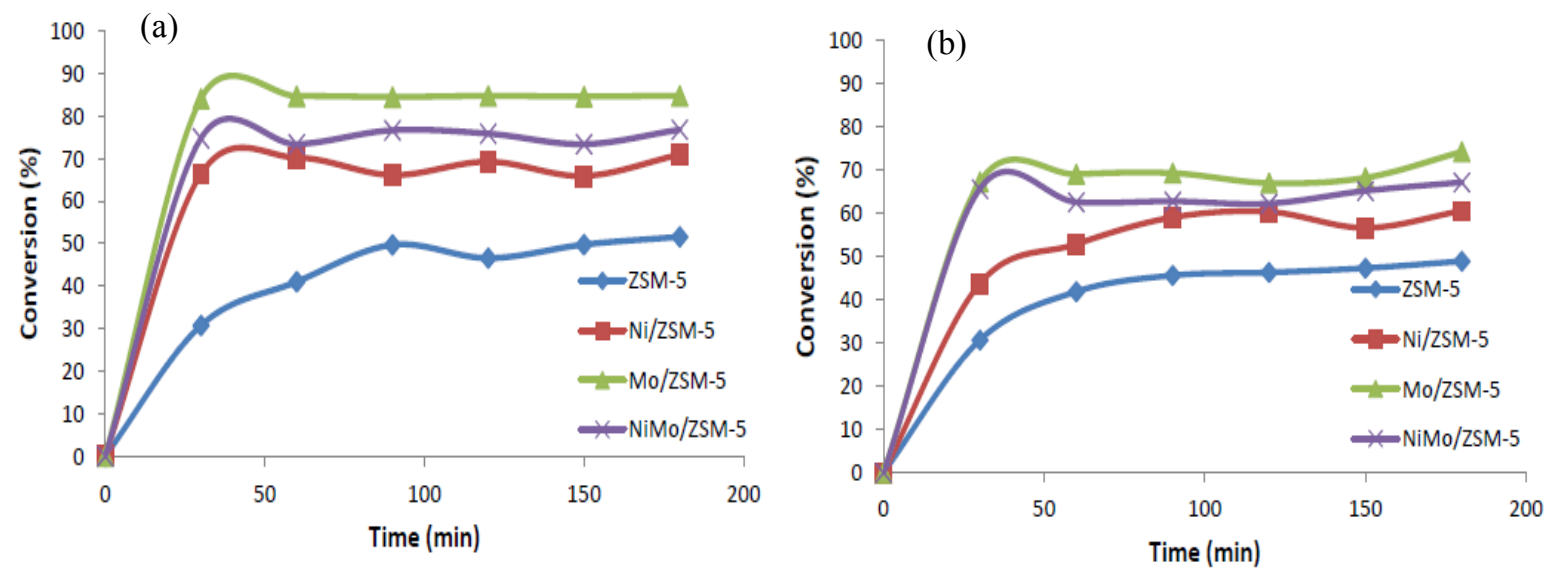

Figure 4. Conversion profiles of UVO with respect to (a) palmitic acid, and (b) stearic acid with different catalyst $\left(\right.$ Temperature $=350^{\circ} \mathrm{C}$, UVO feed WHSV $=4$ hour $\left.^{-1}\right)$

\section{Effect of oxidation state of Metal/ZSM-5 catalyst for catalytic cracking of UVO}

Since Mo/ZSM-5 catalyst towards catalytic cracking reactions of UVO was found to be the best performing catalyst in the present study, Mo/ZSM-5 was then tested with different oxidation states: oxide state and reduced state to study the influence of oxidation state of the metal on zeolite catalyst in catalytic cracking reactions of UVO. The conversion of both palmitic acid and stearic acid over reduced state (Mo/ZSM-5) and oxide phase ( $\left.\mathrm{MoO}_{\mathrm{x}} / \mathrm{ZSM}-5\right)$ catalyst was shown in Figure 5.
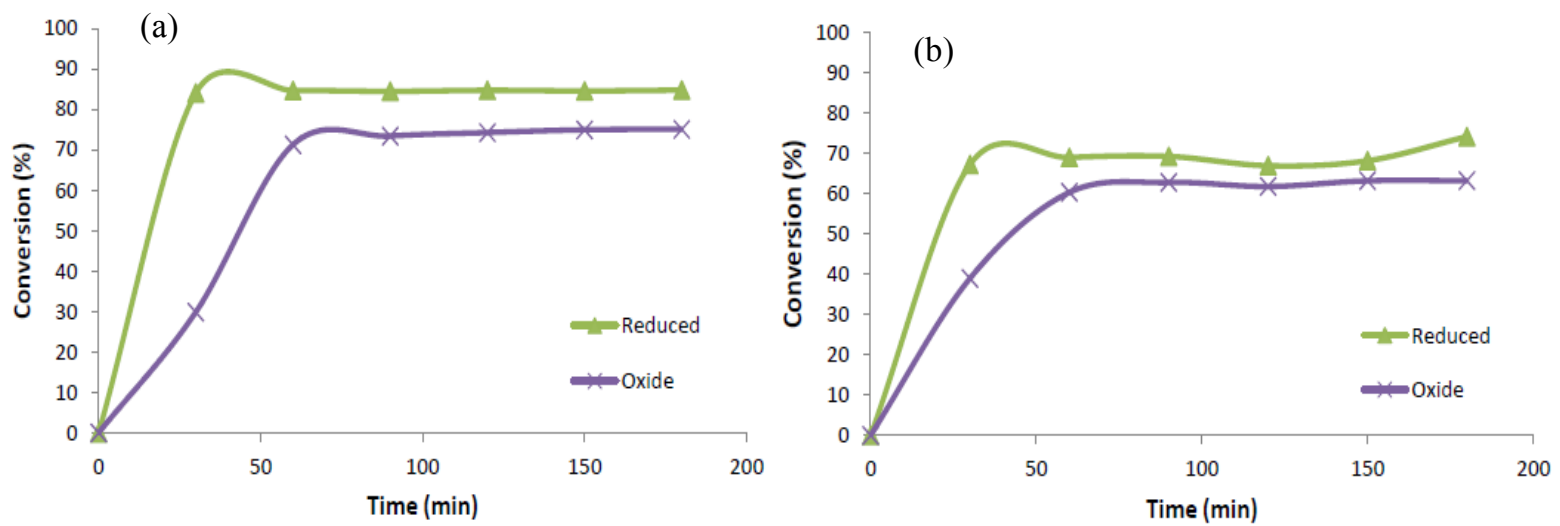

Figure 5. Conversion profiles of UVO with respect to (a) palmitic acid, (b) stearic acid with reduced Mo/ZSM-5 and oxide Mo/ZSM-5 catalyst $\left(\right.$ Temperature $=350^{\circ} \mathrm{C}$, UVO feed WHSV $=4$ hour $^{-1}$ )

From the conversion profile in Figure 5, it was shown that the steady state of the catalytic cracking reaction of UVO was achieved around 90 minutes. It is clear that the conversion profile of reduced molybdenum is better compared to that of the molybdenum oxide. The highest conversion found for reduced Mo/ZSM-5 catalyst was $84.72 \%$ for palmitic acid and $74.10 \%$ for stearic acid. The highest conversion obtained for oxide Mo/ZSM-5 was $75.00 \%$ for palmitic acid and $63.18 \%$ for stearic acid. The catalytic cracking reaction of reduced Mo/ZSM-5 gave better results compared to oxide Mo/ZSM-5. Reduced catalyst would be used in the next section to test the operating temperature in catalytic cracking of UVO. 


\section{Effect of operating temperature for the catalytic cracking of UVO}

The effect of operating temperature for the catalytic cracking reaction of UVO was carried out using the best catalyst with the highest conversion of palmitic acid, reduced Mo/ZSM-5. Effect of temperatures for the catalytic cracking reaction of UVO was carried out at $350{ }^{\circ} \mathrm{C}, 400{ }^{\circ} \mathrm{C}$, and $450{ }^{\circ} \mathrm{C}$. The conversion profile for the palmitic acid was found to be no significant difference in the range of temperature studied. However, slightly higher than average conversion (73.50\%) was observed for stearic acid at $400{ }^{\circ} \mathrm{C}$ in the catalytic cracking of UVO at steady state compared to temperature at $350{ }^{\circ} \mathrm{C}(69.44 \%)$ and $450{ }^{\circ} \mathrm{C}(68.12 \%)$.

Theoretically, the conversion increases with the temperature due to higher kinetic energy possessed by the molecules in the system. In the present case, optimum temperature for conversion of palmitic acid and steric acid is found to be around $350-400{ }^{\circ} \mathrm{C}$. These can be deduced that unwanted reactions start to be significant at temperature higher than $400{ }^{\circ} \mathrm{C}$.

\section{Comparison to catalytic cracking with palladium catalyst}

In the present studies, the highest conversion for palmitic acid and stearic acid over catalytic cracking reaction of UVO was obtained by using Mo/ZSM-5 catalyst at temperature $400{ }^{\circ} \mathrm{C}$. The performance this catalyst was then compared with a promising catalyst, $\mathrm{Pd} / \mathrm{Al}_{2} \mathrm{O}_{3}$ in catalytic cracking of UVO. The commercially obtained $\mathrm{Pd} / \mathrm{Al}_{2} \mathrm{O}_{3}$ was used directly in the reaction. The results obtained from the test were plotted in Figure 6.
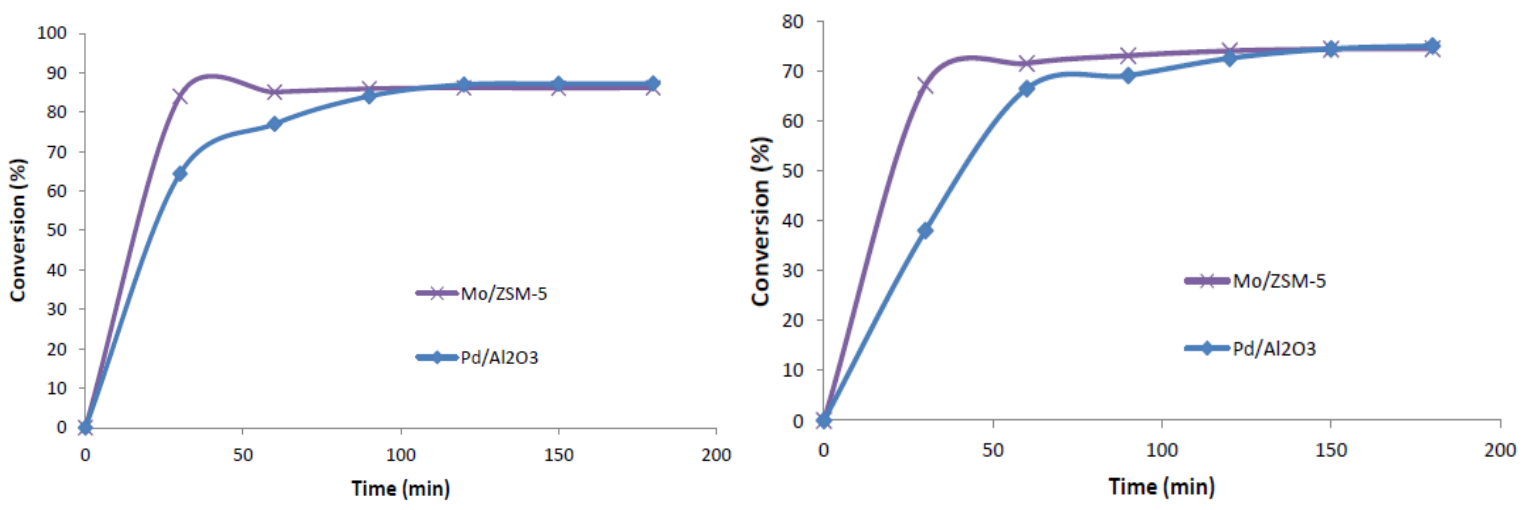

Figure 6. Conversion profiles of UVO with respect to (a) palmitic acid, (b) stearic acid (Temperature $=400{ }^{\circ} \mathrm{C}$, $\mathrm{UVO}$ feed WHSV $=4$ hour $^{-1}$ )

The conversion profile shows that there is no significant difference in terms of the conversion of both palmitic acid and stearic acid for both catalysts after the system reached steady state. However, Mo/ZSM-5 approaches steady state faster at 60 minutes than $\mathrm{Pd} / \mathrm{Al}_{2} \mathrm{O}_{3}$ which is after 120 minutes. In the present study, the conversion remained stable even after 3 hours of operation which showed the catalyst remained active. There is still further study needed to be carried out to have better understanding of the Mo/ZSM- 5 catalyst in catalytic cracking of UVO since coking is commonly reported as an issue in catalytic cracking. Anyhow, Mo/ZSM-5 is found to be an effective catalyst which is much cheaper compared to $\mathrm{Pd} / \mathrm{Al}_{2} \mathrm{O}_{3}$ as catalyst used in catalytic cracking of UVO.

\section{Conclusion}

Catalytic cracking reaction of UVO with Ni, Mo or NiMo functionalized zeolite as catalyst into conventional fuellike hydrocarbons or green fuels was investigated. The two major components in UVO used, palmitic acid and stearic acid, were analysed for their conversions in the reaction. The conversion of the palmitic acid and stearic acid for different catalysts used is in increasing order of ZSM-5 $<$ Ni/ZSM-5 $<$ NiMo/ZSM-5 $<$ Mo/ZSM-5. Mo/ZSM-5 outperformed the other catalysts in the conversion of palmitic acid (84.72\%) and stearic acid (74.10\%). As expected, reduced Mo/ZSM-5 was found to be more effective than $\mathrm{MoO}_{\mathrm{x}} / \mathrm{ZSM}-5$ in the reaction. Among the studied temperature, conducting catalytic cracking of UVO with Mo/ZSM-5 at $400^{\circ} \mathrm{C}$ gives the best results. When 
comparing to $\mathrm{Pd} / \mathrm{Al}_{2} \mathrm{O}_{3}$, a promising catalyst in catalytic cracking of $\mathrm{UVO}$, system with Mo/ZSM-5 is not only giving similar conversion at steady state but also approaches steady state much earlier than $\mathrm{Pd} / \mathrm{Al}_{2} \mathrm{O}_{3}$. Cheaper Mo/ZSM-5 can be deduced a potential favorable catalyst for catalytic cracking of UVO. Nevertheless, further investigation is needed in order to optimize the final product, hydrocarbon yield as there were significant intermediates or side products in the liquid product.

\section{Acknowledgement}

The authors acknowledge the RUI grant (814220) from Universiti Sains Malaysia for carried out the project.

\section{References}

1. Dos Anjos, J. S., De Araujo, G. W, Lam, Y. L. and Frety, R. (1983). Catalytic decomposition of vegetable oil. Applied Catalysis, 5(3): 299-308.

2. Kaplan, S. (2017). Section 10 renewable energy. In: Monthly energy review July 2017, U.S. Energy Information Administration, Office of Energy Statistics, U.S. Department of Energy, Publication number DOE/EIA-0035(2017/7), Washington, DC: pp 156.

3. Fox, J. (2016). World biodiesel production/consumption to rise $14 \%$ by 2020 : OECD/FAO. S\&P Global Platts. https://www.platts.com/latest-news/agriculture/london/world-biodiesel-productionconsumption-to-rise 26485632. [Access online 1 August 2017].

4. Abbasov, V., Mammadova, T., Aliyeva, N., Abbasov, M., Movsumov, N., Joshi A., Lvov Y. and Abdullayev, E. (2016). Catalytic cracking of vegetable oils and vacuum gasoil with commercial high alumina zeolite and halloysite nanotubes for biofuel production. Fuel, 181: 55-63.

5. Natural Fuel (2017). What is the difference between biodiesel and green diesel? http://naturalfuel. com.au/difference-biodiesel-green-diesel/[Acessonline 28 December 2017].

6. Rigutto, M. S., Van Veen, R. and Huve, L. (2007). Chapter 24: Zeolites in hydrocarbon processing. Studies in Surface Science and Catalysis, 168: 855-913.

7. Corma, A. and Martínez, A. (2005). Zeolites in refining and petrochemistry. Studies in Surface Science and Catalysis, 157: 337-366.

8. Di Renzo, F. and Fajula, F. (2005). Introduction to molecular sieves: trends of evolution of the zeolite community. Studies in Surface Science and Catalysis, 157: 1-12.

9. Adjaye, J. D., Katikaneni, S. P. and Bakhshi, N. N. (1996). Catalytic conversion of a biofuel to hydrocarbons: Effect of mixtures of HZSM-5 and silica-alumina catalysts on product distribution. Fuel Processing Technology, 48(2): 115-143.

10. Twaiq, F.A., Zabidi, N.A. and Bhatia, S. (1999). Catalytic conversion of palm oil to hydrocarbons: Performance of various zeolite catalysts. Industrial and Engineering Chemistry Research, 38(9): 3230-3237.

11. Li, H., Shen, B., Kabalu, J. C. and Nchare, M. (2009). Enhancing the production of biofuels from cottonseed oil by fixed-fluidized bed catalytic cracking. Renew Energy, 34(4):1033-1039.

12. Doronin, V. P., Potapenko, O. V., Lipin, P. V. and Sorokina, T. P. (2013). Catalytic cracking of vegetable oils and vacuum gas oil. Fuel, 106: 757-765.

13. Twaiq, F. A., Mohamed, A. R. and Bhatia, S. (2003). Liquid hydrocarbon fuels from palm oil by catalytic cracking over aluminosilicate mesoporous catalysts with various $\mathrm{Si} / \mathrm{Al}$ ratios. Microporous and Mesoporous Materials, 64(1-3): 95-107.

14. Snåre, M., Kubičková, I., Mäki-Arvela, P., Eränen, K. and Murzin, D. Y. (2006). Heterogeneous catalytic deoxygenation of stearic acid for production of biodiesel. Industrial and Engineering Chemistry Research, 45(16): 5708-5715.

15. Lestari, S., Maki-Arvela, P., Bernas, H., Simakova, O., Sjöholm, R., Beltramini, J., Max Lu, G. Q., Myllyoja, J., Simakova, I. and Murzin D.Y. (2009). Catalytic deoxygenation of stearic acid in a continuous reactor over a mesoporous carbon-supported Pd catalyst. Energy \& Fuels, 23(8): 3842-3845.

16. Mäki-Arvela, P., Kubickova, I., Snåre, M., Eränen, K. and Murzin, D.Y. (2007). Catalytic deoxygenation of fatty acids and their derivatives. Energy \& Fuels, 21(1): 30-41.

17. Kubičková, I., Snåre, M., Eränen, K., Mäki-Arvela, P. and Murzin, D. Y. (2005). Hydrocarbons for diesel fuel via decarboxylation of vegetable oils. Catalysis Today, 106(1-4): 197-200. 
18. Hunns, J. A., Arroyo, M., Lee, A. F., Escola, J. M., Serrano, D. and Wilson, K. (2016). Hierarchical mesoporous $\mathrm{Pd} / \mathrm{ZSM}-5$ for the selective catalytic hydrodeoxygenation of m-cresol to methylcyclohexane. Catalysis Science and Technology, 6: 2560-2564.

19. Raut, R., Banakar, V. V. and Darbha, S. (2016). Catalytic decarboxylation of non-edible oils over threedimensional mesoporous silica supported Pd. Journal of Molecular Catalysis A: Chemical, 417: 126-134.

20. Oi, L. E., Choo, M-Y., Suraya, Z., Lee, H.V. and Juan, J. C. (2017). Mesoporous $\mathrm{TiO}_{2}$ : Potential catalyst for deoxygenation of triglyceride to hydrocarbon-like biofuel. Malaysian Journal of Catalysis, 2(2): 53-56.

21. Kordulis, C., Bourikas, K., Gousi, M., Kordouli, E. and Lycourghiotis, A. (2016). Development of nickel based catalysts for the transformation of natural triglycerides and related compounds into green diesel: a critical review. Applied Catalysis B., 181: 156-196.

22. Cejka, J. (2005). Zeolites and ordered mesoporous materials: progress and prospects: the $1^{\text {st }}$ FEZA School on Zeolites, August 20-21, 2005, Gulf Professional Publishing, Prague, Czech Republic.

23. Danilina, N., Krumeich, F., Castelanelli, S. A. and van Bokhoven, J. A. (2010). Where are the active sites in zeolites? origin of aluminum zoning in ZSM-5. Journal of Physical Chemistry C, 114 (14): 6640-6645.

24. Chhetri, A. B., Watts, K. C. and Islam M. R. (2008). Waste cooking oil as an alternate feedstock for biodiesel production. Energies, 1(1): 3-18.

25. Canakci, M., Van Gerpen, J. (2001). Biodiesel production from oils and fats with high free fatty acids. Transactions-American Society of Agricultural Engineers, 44(6):1429-1436.

26. Chiam, L. T. and Tye, C. T. (2013). Deoxygenation of plant fatty acid using $\mathrm{NiSnK} / \mathrm{SiO}_{2}$ as catalyst. Malaysian Journal of Analytical Sciences, 17(1): 129 - 138. 